\title{
PEDAGOGICAL CONCEPT OF TECHNICAL AND TACTICAL TRAINING OF PERSONS WITH DISABILITIES IN CHESS SPORT
}

\author{
I.V. Mikhaylova, chessy07@mail.ru, ORCID: 0000-0002-6402-5210 \\ Russian State Social University, Moscow, Russian Federation
}

\begin{abstract}
Aim. The purpose of the study is to determine the systemic directions and priority ways and develop the stages and technologies for technical and tactical training of people with disabilities for achieving the effective results in chess sport in the long-time perspective. Materials and methods. The empirical study of technical and tactical training conducted in 2005-2015 involved 1275 persons at the age from 10 to 72 years with musculoskeletal disorders, hearing or visual impairments. The criteria for assessing the effectiveness of technical and tactical training were diagnostic questionnaires, specialized chess tests, as well as the following psychodiagnostic techniques: the Spielberger State-Trait Anxiety Inventory (STAI); well-being, activity, mood test ("SAN"-test); The Short Form-36; the UCLA Loneliness Scale. Results. The survey revealed the actual factors hindering effective sports training: difficulties in reaching the training sites, lack of information about chess sections and Internet availability. The upward trend in the technical and tactical training (TTT) dynamics is confirmed by the growth of results due to implementing strategy and tactics - up to $31 \%$; the development of operational thinking - up to $25 \%$; recent memory - up to $27 \%$, evaluative function - up to $31 \%$. As a result of sports training 72 chess players achieved the ranks and titles of The International Chess Federation, including the title of "International Chess Grand Master". Conclusion. The pedagogical concept realized by a set of standard and innovative means, methods, organizational forms of adaptive TTT along with psychological and pedagogical support and comprehensive supervision allows to effectively transform the intellectual potential of a chess player into a sports result.
\end{abstract}

Keywords: chess sport, chess players with disabilities, technical and tactical training, psychological and pedagogical support, performance criteria.

Introduction. The International Olympic Committee recognized chess as a sport in 1999; the world chess movement has up to 605 million participants [1]. The world practice in the field of sports, including its adaptive forms, highlights the technical and tactical component as the central link of the system of sports training. Content analysis of the works of theorists and practitioners of chess sports [A.A. Alekhine (1932), M.M. Botvinnik (1939), L. Polgar (1993), M.I. Dvoretsky (1985), V.A. Bologan (1996), Liu Wenzhe (2003), M. Vershinin (2005), F. Gobet, P.J. Jensen (2005), Dang Van Zung, G.K. Kasparov, M.R. Kobalia (2007), Yu.E. Simkin (2007), V.A. Potkin (2011), Zuong Thanh Bin (2013), Ngo Hyu bien (2014)] did not reveal the unity of ideas about the content and criteria for assessing the effectiveness of technical and tactical training (TTT) $[3,4,7-9$, $11-17,21]$. In addition, it was necessary to consider the global inclusive trends, the existence in any country of the world of up to $10 \%$ of persons with disabilities, as well as modern reforms in chess sport, implemented in changing the rules and time of matches, in the integration of pedagogical and electronic technologies $[2,5]$. Those factors determined the relevance of the study and defined its aim, which is to present the pedagogical concept of adaptive technical and tactical training (TTT) implemented in a set of standard and innovative tools and methods, organizational forms of competition and training activities along with psychological and pedagogical support of persons with disabilities and comprehensive supervision.

Materials and methods. The empirical study of technical and tactical chess training implementation conducted in 2005-2015 involved 1275 persons at the age from 10 to 72 years with musculoskeletal disorders, hearing or visual impairments. The study base comprised the Internet portal "Chess Planet" (domain name - www. chessplanet.ru); Moscow Territorial Social Ser- 


\section{Восстановительная и спортивная медицина}

vice Centers "Alekseevsky" and "Yuzhnoportovy" (TSSCs); Federal State Budgetary Educational Institution of Higher Education "Russian State Social University" (RSSU). At the sports and recreative stage 211 persons were involved into the adaptive chess sport training (TSSCs, 2009-2010); 1018 persons were involved at the initial training stage (RSSU, 2012-2015); 28 persons - at the stage of sports specialization ("Chess planet", 2005 and 2008). In order to identify problems that hinder the effective implementation of sports training, at the first stage of psychological and pedagogical experiments, a survey was organized.

At the second stage, chess players were tested. A set of specialized technical, tactical and psychological tests concerning the dynamics of significant intellectual functions and properties of the individual (recent memory and operational thinking, evaluative function) formed the criteria for assessing the effectiveness of TTT [7, 8]. At the third stage, a comprehensive supervision over the psychophysical activity of chess players with disabilities was carried out according to the generally accepted in the world scientific community scales, namely: the Spielberger StateTrait Anxiety Inventory (STAI), well-being, activity and mood assessment test ("SAN"-test), the quality of life test (The Short Form-36); the subjective feelings of loneliness test (D. Rassell and M. Ferguson test) $[6,10,19,20]$. Mathematical and statistical data processing was carried out using the average values methods, factor and correlation analysis.

Results and discussion. The distinguishing characteristic of chess sport is an integrated combination of components of technical and tactical training in the concept, which refers to the degree of development of mental actions and the characteristics of the sports discipline "chess", as well as the ability of the chess player to conduct intellectual combat in the process of competitive activity using a variety of tactics, techniques and forms of their implementation. As a theoretical and methodological basis, the concepts of programmed learning and systematic and gradual formation of mental actions and concepts were used [18]. The pedagogical concept of TTT was implemented by standard and innovative means, methods, organizational forms of tactical and technical training, the optimal combination of psychological and pedagogical support and implementation of comprehensive control over the psychophysical activity of chess players with disabilities. Along with the standard means of chess training, the Internet portal "Chess Planet", the public chess training platform "Chess Lessons by Anatoly Karpov", the author's electronic database "Schematic Thinking", as well as other chess software that created a developed electronic environment for the implementation of the TTT were used. As the main methods circuit training, the real time training and the method of individual tasks were implemented; organizational forms of TTT were represented by the integration of full-time, remote and electronic forms. The dynamics of indicators for assessing the effectiveness of adaptive TTT can be detailed as follows. The results of the survey revealed the most significant factors impeding the effective implementation of the TTT (varying in points on a scale from 1 - "absolutely irrelevant" to 10 - "absolutely relevant"), namely: at the sports and recreation stage - "Lack of information about chess interest groups, sections and clubs" (xM = 9.21); at the stage of initial training - "Lack of free Internet access" ( $\mathrm{xM}=9.10)$; at the stage of sports specialization - "Inability to reach the training sites" $(\mathrm{xM}=9.21)$.

The choice of the technical and tactical tests presented in the table 1 was determined by the tasks and requirements of the specific stage of preparation. It should be noted that the maximum growth rates in technical and tactical tests were achieved at the sports and recreation stage (up to $106 \%$ ), while the tests aimed at the assessment of intellectual properties and functions were not carried out, since the requirements of the Federal standards of sports training do not apply to this stage. The maximum growth rates in the results of intellectual properties and functions of individuals were achieved at the stage of initial training (up to $31 \%$ ). This was due to the inclusive trends in the sports training in regard to RSSU students: the subjects practiced together the following Chess World, Europe and the Olympic Games Champions: S.A. Karyakin, V.E. Gunina, O.A. Girya, Ya.A. Nepomnyachy, E.K. Inarkiev.

Comprehensive supervision of the psychophysical activity of chess players with disabilities revealed the following dependencies: according to the assessment of anxiety, the maximum decrease in personal and situational anxiety was observed at the stage of initial training - from 31 to $35 \%$, respectively, and the average decrease in personal and situational anxiety in all stages of sports training amounted to 28 and $29 \%$ respectively. 
Dynamics of indicators for assessing the effectiveness

Table 1 of adaptive chess technical and tactical training $(n=1257)$

\begin{tabular}{|c|c|c|}
\hline \multicolumn{3}{|c|}{ Sports and recreative stage; $(n=211)$} \\
\hline \multicolumn{2}{|c|}{ Criteria for evaluating the effectiveness of technical and tactical training } & The rate of growth* $(\%)$ \\
\hline \multirow{2}{*}{ Specialized technical and tactical tests } & Game rules & +65 \\
\hline & The ability to play & +106 \\
\hline \multicolumn{3}{|c|}{ The initial stage of chess sport training; $(n=1018)$} \\
\hline \multirow{5}{*}{ Specialized technical and tactical tests } & Chess opening & +40 \\
\hline & Endgame & +32 \\
\hline & Strategy & +31 \\
\hline & Tactics & +31 \\
\hline & Game rules & +29 \\
\hline \multirow{3}{*}{$\begin{array}{l}\text { Tests evaluating intellectual properties } \\
\text { and functions }\end{array}$} & Recent memory & +27 \\
\hline & Operational thinking & +25 \\
\hline & Evaluative function & +31 \\
\hline \multicolumn{3}{|c|}{ Stage of sports specialization; $(n=28)$} \\
\hline \multirow{5}{*}{ Specialized technical and tactical tests } & Chess opening & +24 \\
\hline & Middlegame & +25 \\
\hline & Endgame & +26 \\
\hline & Strategy & +25 \\
\hline & Tactics & +29 \\
\hline \multirow{3}{*}{$\begin{array}{l}\text { Tests evaluating intellectual properties } \\
\text { and functions }\end{array}$} & Recent memory & +20 \\
\hline & Operational thinking & +20 \\
\hline & Evaluative function & +21 \\
\hline
\end{tabular}

*at $\mathrm{p} \leq 0,05$

The positive dynamics of the growth in the results was observed in the SAN-test with a significant spread of indicators of well-being, activity, mood from 16 to $34 \%$. The maximum decrease in the level of subjective feeling of loneliness was achieved at the stage of sports specialization and amounted to $43 \%$, with an average decrease of $36 \%$ at all stages of sports training.

The results of the SF-36 test revealed an improvement in the psychological health of chess players with disabilities by $16 \%$ with a slight increase in the physical component by $4 \%$.

\section{Conclusion}

1. Content analysis of domestic and foreign studies revealed the lack of theoretical justification of the system of technical and tactical training taking into account not only modern reforms in chess sport, but also the requirements of adaptation of content, tools, methods and organizational forms to the health status of chess players.

2. Significant factors impeding the effective implementation of adaptive chess technical and tactical training were ranked.

3 . The means, methods and organizational forms of technical and tactical training creating a developed electronic environment of chess competitive training activities were defined.
4. The criteria for evaluating the effectiveness of technical and tactical training represented by a set of specialized chess tests to assess the development level of technical and tactical skills and recent memory dynamics, operational thinking and evaluative function of chess players with disabilities were drawn up.

5. It is established that the pedagogical concept of adaptive chess technical and tactical training implemented in a set of standard and innovative tools, methods, organizational forms of technical and tactical training along with psychological and pedagogical support taking into account the heterogeneity of the target population and comprehensive psychological and pedagogical supervision, is effective and has no analogues in the world.

As a result of sports training, the intellectual potential of chess players with disabilities was transformed into a sports result - 72 chess players achieved the ranks in compliance with the Unified Sports Classification System of Russia.

A.V. Gabrielyan became an international grandmaster, A.V. Komissarov won the World Champion title among visually impaired chess players as a member of the Russian national team. 


\section{Восстановительная и спортивная медицина}

\section{References}

1. 605 millionov vzroslykh lyudey igrayut $v$ shakhmaty, $i$ drugaya statistika ot $A G O N a$ [605 Million Adults Play Chess, and Other Statistics from Agon Limited]. Available at: http://chessnews.ru/node/8930 (accessed 18.01.2019).

2. Alifirov A.I., Mikhaylova I.V., Makhov A.S. et al. [Theoretical and Practical Aspects of the Chess Sport Introduction in the Russian School]. Teoriya i praktika fizicheskoy kul'tury [Theory and Practice of Physical Culture], 2018, no. 5, pp. 53-55. (in Russ.)

3. Kalinin A.V. Shakhmaty. Kak trenirovat'sya budushchim masteram [Chess. How Future Masters Should Practice in Chess]. Moscow, Russian CHESS Publ., 2015. 224 p.

4. Kasparov G.K. Moi velikiye predshestvenniki: Noveyshaya istoriya razvitiya shakhmat. igry [My Great Predecessors. The Latest History of the Chess Game Development]. Moscow, Ripol Classic Publ., 2006, vol. 5. 527 p.

5. Mikhaylova I.V., Alifirov A.I. [Chess for Persons with Mental and Intellectual Disabilities]. Teoriya $i$ praktika fizicheskoy kul'tury [Theory and Practice of Physical Culture], 2017, no. 3, pp. 46-47. (in Russ.)

6. Raigorodskiy D.Ya. Entsiklopediya psikhodiagnostiki. Psikhodiagnostika vzroslykh [Encyclopedia of Psychodiagnostics. Psychodiagnostics in Adults]. Samara, Bahrah-M Publ., 2015. 704 p.

7. Simkin Yu.E., Sukhanov V.Yu, Bartashnikov A.A. [Objective Diagnostics of Chess Players Recent Memory]. Teoriya i praktika fizicheskoy kul'tury [Theory and Practice of Physical Culture], 1984, no. 2, pp. 55-56. (in Russ.)

8. Simkin Yu.E., Sukhanov V.Yu., Braslavsky V.R. [Methods of Objective Diagnostics of Chess Players Operational Thinking Based on the Test Chess Problems Solving]. Teoriya i praktika fizicheskoy kul'tury [Theory and Practice of Physical Culture], 1986, no. 5, pp. 38-39. (in Russ.)
9. Shereshevsky M.I. Moya metodika.

Ot razryadnika - $k$ grossmeysteru [My Technique. From Ranked Sportsmen to Grandmaster]. Moscow, Russian Chess Federation Publ., 2017. $368 \mathrm{p}$.

10. American Psychological Association. The State-Trait Anxiety Inventory (STAI). Available at: https:/www.apa.org/pi/about/publications/ caregivers/practice-settings/assessment/tools/ trait-state.aspx/ (accessed 18.01.2019).

11. Benjamin J. Small Steps to Giant Improvement. Alkmaar: New in Chess Publ., 2018. $224 \mathrm{p}$.

12. Carsten H. Vladimir Kramnik - The Inside Story of a Chess Genius. Glasgow: Quality Chess Publ., 2018. 256 p.

13. Cripe K. The Learning Spiral: A New Way to Teach and Study Chess. Boston: Mongoose Press Publ., 2018. 510 p.

14. Dvoretsky M. Recognizing Your Opponent's Resources: Developing Preventive Thinking. Milford: Russell Enterprises, Inc., 2015. 360 p.

15. Gelfand B. Dynamic Decision Making in Chess. Glasgow: Quality Chess Publ., 2016. 288 p.

16. Polgar L. Nevelj zsenit! Budapest: Interart Publ., 1989. 109 p.

17. Shankland S. Small Steps to Giant Improvement. Glasgow: Quality Chess Publ., 2018. $336 \mathrm{p}$.

18. Skinner B.F. The Technology of Teaching. New York: Copley Publishing Group Publ., 2003. 271 p.

19. The National Center for Biotechnology Information. SF-36 Total Score as a Single Measure of Health-Related Quality of Life: Scoping Review. Available at: https://www.ncbi. nlm.nih.gov/pmc/articles/PMC5052926/ (accessed 18.01.2019).

20. The National Center for Biotechnology Information. UCLA Loneliness Scale (Version 3): Reliability, Validity, and Factor Structure. Available at: https:/www.ncbi.nlm.nih.gov/pubmed/ 8576833 (accessed 18.01.2019).

21. Wenzhe L. The Chinese School of Chess. London: Batsford Publ., 2002. 290 p.

Received 19 September 2019 
Удк 794.1

DOI: $10.14529 / \mathrm{hsm} 190413$

\title{
ПЕДАГОГИЧЕСКАЯ КОНЦЕПЦИЯ \\ ТЕХНИКО-ТАКТИЧЕСКОЙ ПОДГОТОВКИ ЛИЦ С ОТКЛОНЕНИЯМИ В СОСТОЯНИИ ЗДОРОВЬЯ В ШАХМАТНОМ СПОРТЕ
}

\author{
И.В. Михайлова \\ Российский государственный социальный университет, г. Москва, Россия
}

Цель исследования: определение системных направлений, приоритетных путей, разработка этапов и технологий технико-тактической подготовки лиц с отклонениями в состоянии здоровья для достижения эффективных результатов в шахматном спорте на долгосрочную перспективу. Материалы и методы. В эмпирическом исследовании процессов реализации технико-тактической подготовки, проведенном в период 2005-2015 гг., приняли участие 1257 лиц от 10 до 72 лет, имеющие поражения опорно-двигательного аппарата, слуха, зрения. База исследования: Интернет-портал «Шахматная Планета» (www.chessplanet.ru); территориальные центры социального обслуживания населения «Алексеевский», «Южнопортовый» г. Москвы; ФГБОУ ВО «Российский государственный социальный университет». Критериальную базу оценки эффективности техникотактической подготовки составили диагностическое анкетирование, специализированные шахматные тесты, а также тесты динамики оперативного мышления, оперативной памяти, оценочной функции. Комплексный контроль над психофизической активностью шахматистов был проведен по психодиагностическим методикам: оценки тревожности (по Ч.Д. Спилбергеру), самочувствия, активности, настроения (по тесту САН), качества жизни (The Short Form-36); субъективного ощущения одиночества (по Д. Расселу и М. Фергюсону). Математико-статистическая обработка данных осуществлялась методами средних величин, факторным и корреляционным анализом. Результаты. Анкетирование выявило актуальные факторы, препятствующие эффективной спортивной подготовке: сложности при транспортировке к местам тренировок, отсутствие информации о шахматных секциях и доступного Интернета. Восходящий тренд динамики техникотактической подготовки подтверждается финальными темпами прироста результатов, в том числе: по стратегии и тактике - до $31 \%$, при развитии интеллектуальных качеств по оперативному мышлению - до $25 \%$, оперативной памяти - до $27 \%$, оценочной функции - до 31 \%. В результате спортивной подготовки 72 шахматиста выполнили разряды и звания Международной шахматной федерации, включая титул «Международный гроссмейстер по шахматам». Заключение. Педагогическая концепция, реализуемая совокупностью стандартных и инновационных средств, методов, организационных форм адаптивной технико-тактической подготовки в единстве с психолого-педагогическим сопровождением и комплексным контролем, позволяет эффективно преобразовать интеллектуальный потенциал шахматиста в спортивный результат.

Ключевые слова: шахматный спорт, шахматисты с отклонениями в состоянии здоровья, технико-тактическая подготовка, психолого-педагогическое сопровождение, критерии эффективности.

\section{Лuтература}

1. 605 миллионов взрослых людей играют в шахматы, и другая статистика от АГОНа // Новости шахмат. - http://chess-news.ru/node/8930 (дата обращения: 18.01.2019).

2. Алифиров, А.И. Теоретические и практические аспекты внедрения шахмат в российской школе / А.И. Алифиров, И.В. Михайлова, А.С. Махов и др.// Теория и практика физ. культуры. 2018. - № 5. - C. 53-55.

3. Калинин, А.В. Шахматы. Как тренироваться будущим мастерам / А.В. Калинин. - М.: Russian CHESS House, 2015. - 224 c.

4. Каспаров, Г.К. Мои великие предшественники: Новейтая история развития шахматной игры. В 7 т. Т. 5: Карпов и Корчной / Г.К. Каспаров. - М.: Рипол Классик, 2006. -527 с. 


\section{Восстановительная и спортивная медицина}

5. Михайлова, И.В. Шахматы для лии с нарушениями психического и интеллектуального развития / И.В. Михайлова, А.И. Алифиров // Теория и практика физ. культуры. - 2017. - № 3. C. $46-47$.

6. Райгородский, Д.Я. Энщиклопедия психодиагностики. Психодиагностика взросльх / Д.Я. Райгородский. - Самара: Издат. дом «Бахрах-М», 2015. - 704 с.

7. Симкин, Ю.Е. Методика объективной диагностики оперативного мышления шахматистов на основе тестовых шахматных задач / Ю.Е. Симкин, В.Ю. Суханов, В.Р. Браславский // Теория и практика физ. культуры. - 1986. - № 5. - С. 38-39.

8. Симкин, Ю.Е. Объективная диагностика оперативной памяти у шахматистов-спортсменов / Ю.Е. Симкин, В.Ю. Суханов, А.А. Барташников // Теория и практика физ. культуры. 1984. - № 2. - C. 55-56.

9. Шерешевский, М.И. Моя методика. От разрядника - к гроссмейстеру / М.И. Шерешевский. - М.: Рос. шахматная федерачия, 2017. - 368 c.

10. American Psychological Association. The State-Trait Anxiety Inventory (STAI). - https://www. apa.org/pi/about/publications/caregivers/practice-settings/assessment/tools/trait-state.aspx/ (dama oбращения: 18.01.2019). $224 p$.

11. Benjamin, J. Small Steps to Giant Improvement / J. Benjamin. - Alkmaar: New in chess, 2018. -

12. Carsten, H. Vladimir Kramnik - The Inside Story of a Chess Genius / H. Carsten. - Glasgow: Quality Chess, 2018. - $256 p$.

13. Cripe, K. The Learning Spiral: A New Way to Teach and Study Chess / K. Cripe. - Boston: Mongoose Press, 2018. - 510 p.

14. Dvoretsky, M. Recognizing Your Opponent's Resources: Developing Preventive Thinking / M. Dvoretsky. - Milford: Russell Enterprises, Inc., 2015. - 360 p.

15. Gelfand, B. Dynamic Decision Making in Chess / B. Gelfand. - Glasgow: Quality Chess, 2016. $288 \mathrm{p}$

16. Polgar, L. Nevelj zsenit! / L. Polgar. - Budapest: Interart Publ., 1989. - 109 p.

17. Shankland, S. Small Steps to Giant Improvement / S. Shankland. - Glasgow: Quality Chess, 2018. - $336 p$.

18. Skinner, F. The Technology of Teaching / F. Skinner. - New York: Copley Publishing Group, 2003. $-271 p$.

19. The National Center for Biotechnology Information. SF-36 total score as a single measure of health-related quality of life: Scoping review. - https://www.ncbi.nlm.nih.gov/pmc/articles/PMC5052926/ (дата обращения: 18.01.2019).

20. The National Center for Biotechnology Information. UCLA Loneliness Scale (Version 3): reliability, validity, and factor structure. - https://www.ncbi.nlm.nih.gov/pubmed/8576833 (dama oбращения: 18.01.2019).

21. Wenzhe, L. The Chinese School of Chess/L. Wenzhe. -London: Batsford, 2002. - 290 p.

Михайлова Ирина Витальевна, кандидат педагогических наук, доцент, доцент кафедры теории и методики физической культуры и спорта, Российский государственный социальный университет. 129226, г. Москва, ул. Вильгельма Пика, дом 4, стр. 1. E-mail: chessy07@mail.ru, ORCID: 0000-0002-6402-5210.

Поступила в редакцию 19 сентября 2019 г.

\section{ОБРАЗЕЦ ЦИТИРОВАНИЯ}

Mikhaylova, I.V. Pedagogical Concept of Technical and Tactical Training of Persons with Disabilities in Chess Sport / I.V. Mikhaylova // Человек. Спорт. Медицина. - 2019. - Т. 19, № 4. - C. 111-116. DOI: $10.14529 / \mathrm{hsm} 190413$

\section{FOR CITATION}

Mikhaylova I.V. Pedagogical Concept of Technical and Tactical Training of Persons with Disabilities in Chess Sport. Human. Sport. Medicine, 2019, vol. 19, no. 4, pp. 111-116. DOI: $10.14529 / \mathrm{hsm} 190413$ 